\title{
CONTEMPORARY FIQH METHODOLOGY IN THE THEORY OF THE LIMITATION OF DIALECTICS SPACE AND TIME ACCORDING TO MUHAMMAD SYAHRUR
}

\author{
Sakirman \\ Institut Agama Islam Negeri (IAIN) Metro \\ Jl. Ki Hajar Deantara 15A, Iringmulo, Metro, Lampung \\ Email : sakirman@metrouniv.ac.id
}

\begin{abstract}
The hudūd Syahrur theory is designed to manifest fiqh apart from the dominance of the tyrannical system as it occurs in classical Islamic figh. This theory wants to realize the Islamic law that is formed in the corridor of the law (al-fiqh al-dustür). According to Syahrur, the need for al-fiqh al-dustür is very urgent because the fiqh of Islam that has been so far is relying on the character (fuqaha) personally, not institutional. Syahrur assumes that in the field of law, the Islamic world is currently experiencing an acute crisis. Therefore, he considers that the existence of new fiqh formed based on new methods is very urgent to be realized. The hudüd theory is part of a new method proposed by Syahrur in contemporary Islamic legal thought. Therefore, this paper examines aspects of contemporary methodology in hudud theory concept initiated by Muhammad Syahrur.
\end{abstract}

Abstrak. Teori hudūd Syahrur dirancang untuk mewujudkan fiqh yang terlepas dari dominasi sistem tirani sebagaimana yang terjadi dalam fiqh Islam klasik. Teori ini ingin mewujudkan hukum Islam yang terbentuk dalam koridor undang-undang (al-fiqh aldusturì). Menurut Syahrur, kebutuhan akan al-fiqh al-dusturī sangat mendesak karena fiqh Islam yang ada selama ini sangat bertumpu pada tokoh (fuqaha) secara pribadi, bukan kelembagaan. Syahrur beranggapan bahwa dalam bidang hukum, dunia Islam saat ini sedang mengalami krisis akut. Oleh karena itu, ia memandang bahwa adanya fiqh baru yang dibentuk berdasarkan metode baru sangat mendesak untuk diwujudkan. Teori hudūd merupakan bagian dari metode baru yang diusulkan Syahrur dalam pemikiran hukum Islam kontemporer. Oleh karena itu, tulisan ini mengkaji aspek metodologi kontemporer dalam konsep teori hudud yang digagas oleh Muhammad Syahrur.

Keywords: Muhammad Syahrur, hudud, Syria, Islamic law, contemporary DOI: http://dx.doi.org/10.24239/jsi.v14i2.484.301-326 


\section{Introduction}

The hudūd theory is a proof that Syahrur is aware of the decreasing function of Islamic law that occurred since the nineteenth century into a law which deals with only personal issues due to the urgency of European / Western modernity. Although since 1970 the expression to restore the vitality of Islamic law in the public domain began to appear with the emergence of codification of Islamic family law in various countries and the growth of discussions on actual themes, such as Islamic Banking and insurance, but the problematic of making Islamic law as public law remains an obstacle to Muslim society in the modern world. This constraint grew heavier after the fuqaha seemed reluctant to make Islamic law as a truly effective public legal system. With his hudūd theory Syahrur seeks to overcome this acute problem and expects Islamic law to be a law that truly lives in modern society.

The emergence of the hudūd Syahrur theory actually can not be separated from the efforts of the originator to pack Islamic law in the context of nation-state by paying attention to new conceptions that are well received, such as constitution, democracy, opposition, pluralism, civil society, and upholding the rights of the people. This is important because since Islamic law has its 3rd-century developmental phase (XIX to the present), the problematic of how to package Islamic law in a nation-state container is a fundamental problem that never ages. If in the first phase, the formation phase (VII-X century AD), Islamic law is highly creative and flexible with customs and local communities; in the second phase (X-XIX century), Islamic law appears to be static (Immutable) and rigid, then in the third phase of Islamic law seems to begin to interact with the idea of nation-state. In this phase, awareness to reform the law began to develop among the Muslim community, because the irrelevance of Islamic law with the modern world is felt increasing. 
The condition of the Syrian, Middle Eastern and Muslim worlds on average has problems in enforcing democracy and civil liberties in all walks of life affecting the emergence of hudūd theory. Not only this democracy and civil liberty has encouraged the intellectuals, it also encourage both Syrians and other Muslim worlds to find the right formula for the relationship between atturâts and al-hadâtsah and between state and religion. In the Middle East context, the problem has led people to fall into various problems, such as neo-colonialism, poverty, powerlessness, corruption and economic inequality, radicalism, accusations of terrorism, marginalization, and intellectual crisis. In the context of the Islamic world, the problem has brought the Muslim community down into its noose-like situation, such as the tolerance, the problems of modernity and the adjustment of crisis, to the endless political problems. The hudūd theory proposed by Syahrur to uphold democracy and civil liberties with the priority of democracy enforcement in the field of Islamic law.

Muslims today need new fiqh that has been organized based on the foundations of the new epistemology of knowledge and new life problems as well. The importance of the new fiqh based on the new epistemological foundations of knowledge and new life problems is well recognized by Syahrur, given that the great schools of fiqh that existed have been based on the existing system of knowledge and are part of the process of interaction between Islam and certain historical locality that the fuqaha experienced with its various political, economic and social factors.

Syahrur states two important points of historical fiqh that led to the emergence of a prolonged crisis to the present; first, the historical figh is formed on the assumption that the hudūd of Allah is the tasyri' 'aini, concrete and specific that man in the field of law becomes very small; Secondly, the state is separated from religion, so fiqh is never been effective as a state law capable of organizing citizens widely. Thus, the changing circumstances and development of the present life context have demanded the 
creation of a new Islamic law. The hunt for Islamic law must be done by combining the naqli sciences with the logical sciences that are always evolving all the time, so that the irelevance problem can be gradually solved. The hudūdtheory is an alternative that will be tested by history, the fate of this theory will continue to grow or die highly dependent on the results of the historical selection of modern thinking.

The emergence of hudüd theory is also encouraged by the spirit to reformulate the science of ushul fiqh so that it can be delivered to modern Islamic law. Syahrur wants to change the original Islamic law from the law of the sky became the law of the earth who heed the signs of the sky. As an effort to ground Islamic law, Syahrur's thinking in the field of law is clearly influenced by the principles of the new world order, such as nation-state, civil state, democracy, power sharing, and the principle of acceptability and public accountability. On the one hand Syahrur wants to be realistic about the political order of the law of the modern world, but on the other hand he wants to remain faithful to the guidance of revelation. His solution is to make Islamic law a law that is legally produced by modern political structures and institutions. This solution he chooses based on contemporary socio-historical reality in which almost all modern states view parliament as a legitimate representative body of the people.

The theory of hudūd Syahrur is closely related to the perspective of the originator of the treatise brought by Muhammad as the end-time prophet and apostle. The hudud theory is part of Syahrur's attempt to keep Muhammad's message alive and relevant to the reality of the age to the end of time. The hudūd theory is a concrete manifestation of the paradigm that Syahrur has in understanding Islam as a universal religion, hanif and hudūdi without using such a paradigm hudūd theory would be difficult to understand. 


\section{Biography Sketch of Muhammad Syahrur}

Muhammad Syahrur Deyb was born in Damascus, Syria, on March 11, 1938. His primary education and middle-aged aducation was at the educational institution Abd al-Rahman al-Kawakibi, Damascus and completed in 1957. He was then awarded with a government scholarship to study civil engineering (handasah madaniyyah) in Moscow , The Soviet Union, in March 1957, earned a Diploma in civil engineering in 1964. Later that year he worked as a lecturer at the Faculty of Engineering at the University of Damascus; he was then sent by the university to Ireland National University to obtain his Masters and Doctoral degrees in Mechanics Defense and Foundation until he obtained his Master of Sience degree in 1969 and his Doctorate degree in 1972. Until now, Muhammad Syahrur is still teaching at the Faculty of Civil Engineering at Damascus University in the field of Defense Mechanics in Damascus. ${ }^{1}$

In 1982 - 1983, Syahrur was sent back by the university to become an expert on Al-Saud Consult, Saudi Arabia. He also with some of his colleagues at the Faculty opened a Giro Consulate of Dār al-Istisharah al-Handasiyyah Technique in Damascus. He also mastered English and Russian, in addition to his mother tongue Arabic. Besides, he also pursue the field of interest that is the Philosophy of Humanism and Deepening the meaning of Arabic. His writings are widely spread in Damascus, especially in his field of specialization including building foundation techniques in three volumes and soil mechanics. ${ }^{2}$

As for his book al-Kitab wa al-Qur'ān: Qirā'ah Mu'așirah which provoked the reaction of pros and cons which was completed in a long term (from 1970 to 1990). To be exact since he was in the process of writing his doctoral dissertation in Ireland until published in 1992, by Sina Publisher and Al-Halli, avant Garde

${ }^{1}$ M. Abied Shaleh, Islam Garda Depan (Bandung: Mizan, 2001), 237. ${ }^{2}$ Ibid. 
publishers of the enlightenment movement (called secular groups) in Egypt today.

The publication of the book recognized by Jamal Al-Banna, an Egyptian Muslim intellectual, the labor movement and the younger brother of Hasan Al-Banna, the new method of interpreting the Qur'anic text of the holy book has trigger loud controversy, and then other books emerged, from the pro and the cons. Among those that can be mentioned here is the book Tahâfut Qirā'ah Mu'âsirah by Munir Muhammad Thahir al-Syawwaf a law scholar from Lebanon and al-Furqān wa al-Qur'ān by Shaykh bin Abd al-Eahman al-Akk and there are still many books of rebuttal and denial of the work of Muslim thinkers. ${ }^{3}$

Globally this contemporary book reading (Qirā'ah Mu'āșirah) can be divided into two groups. The first, and the most important part, is the basic ideas consisting of the methodological rules which form the basis of his thinking in the interpretation of the Quranic Text. The second is the result of basic thought and methodology. After completing his study of the interpetation of Gender Signs in his book. Syahrur then launched his latest book which is also the result of a contemporary reading methodology entitled al-Dirāsah al-Mu'āșirah fí al-Daulah wa al-Mujtama'. This book was immediately followed by the publication of "Tahāfut al-Dirāsah alMu'àsirah fĩ al-Daulah wa al-Mujtama' by Munir Al-Syawwaf. ${ }^{4}$

Contemporary Fiqh Methodology: the Qur'an, Sunnah, and Hudūd Theory

\section{Al-Quran}

According to Syahrur, the Qur'an in the popular sense, or in the Syahrur Al-Kitab, is divided into three kinds: 1) umm al-kitāb (muhkamāt verses), 2) al-Qur'ān wa sab'u al-mathānī (mutashābihāt verse), and 3) tafsīlu al-Kitāb. Umm al-Kitāb, which

\footnotetext{
${ }^{3}$ Sahiron Syamsudin, Metodologi Fiqh Islam Kontemporer (Yogyakarta: el-SAQ Press, 2004), 1.

${ }^{4}$ Ibid,. 2
} 
was revealed directly from God to the Prophet for 23 years in the form of al-inzāland al-tanzīl inseparably. According to him, in the relation of Al-Kitab contains verses related to al-sulūk al-insānīin the field of law and morals and open for ijtihad (not in pure worship) in accordance with the circumstances of certain people. ${ }^{5}$

The result of the intellectual interaction of the people with the Umm al-Kitāb at one time may be different from the results of their interactions at another time. Therefore, according to him, the practice of applying the law in the time of the Prophet (read: alSunnah) is only the initial model of interpretation, and is not the only appropriate form of law application of the Umm al-Kitāb throughout the ages. The elasticity of the understanding and application of the Umm al-Kitäb is referred to as hanafiyah, which is certainly the aspects of istiqamat (legal consistency), namely alhadd al-adnā (minimal legendary limit) and al-hadd al-a'lā (limit legis maximum) is also always considered. Besides being elastic, Umm al-Kitāb is also subjective, in the sense that the elasticity of all the rules of law, norms and morals contained in the Umm alKitāb is very dependent on the endeavor (choice) of man. ${ }^{6}$

In interpreting the holy book of the Qur'an Syahrur relies on Abu Ali Al-Farisi's semantic method which can be found in the treasures of Ibn Jinni and Abd al-Qadir al-Jurjani. Besides, he also uses modern linguistic science with the premise that all oral humanitarians including verbal and oral do not have a single word synonymous. Thus, a word meaning can be reduced by the process of historical evolution or beyond it can also bring more meaning than other similar words, but not the same. In this case, Tsa'lab has a famous postulate: "Ma yużann fí al-dirāsah al-lughawiyyah min al-mutarädifät". (What was previously suspected in the study of language as synonymous words is actually among words that have

\footnotetext{
${ }^{5}$ Muhammad Sahrur, Al-Kitab Wal-Qur'an : Qira'ah Mu'ashirah (Kairo: Sina Publisher, 1992), 34-37.

${ }^{6}$ Ibid.
} 
different meanings). Therefore, Syahrur chose Ibn Faris's Muqayas al-Lughah Dictionary as the main reference in finding the difference in the meaning of the words he studied.

Thus the Qur'an in the typical sense of the Shah means a certain part of the holy book on the subject of objective science. The Qur'an was originally read and understood not through the prism of centuries of jurispendenci, but as if the Messenger of Allah had just died and told us about the book. This in turn deconstructs and reconstructs well-established concepts, theories and paradigms into mainstream understanding, thinking and even the confidence of the majority of Muslims.

With linguistic eyeglasses, the Qur'an is declared as an authentic Arabic book that has two sides of literary miracles (alI'jāz al-balāghì) using a descriptive-signification approach (almanhaj al-wașfi al-wazijî) and scientific (al-Ijjāz al-ilm) which is observed using a historical-scientific approach (al-manhaj altārikh al-ilmì).

The literary approach is done by combining literary analysis (balaghah) and grammatical analysis (nahwu). Both disciplines are usually examined separately, thus eliminating the potential of both as a tool for analyzing religious texts critically. Meanwhile, the second approach demands the rejection of the phenomenon of synonymity (al-tarāduf) in the language and demands an in-depth study of every term that has been considered synonymous. Furthermore, Syahrur also asserts his assumption that the Qur'an as a revelation to man, is revealed to be comprehensible in its entirety. Allah has given guidance for man to reveal the secret of his message. This guide is a method of understanding the Qur'an which Syahrur calls the term manhaj al-tartīl, which can be identified with the method of intertextuality. Furthermore, Syahrur laid this method as one of the main principles in the hermeneutics of the Qur'an which he termed al-takwil. 


\section{Sunnah}

Speaking of the sunnah, Syahrur gives his own terminology based on his interpretation of the verses of the Qur'an that speak on the Prophet's position. He distinguished the Sunna (Role of the Apostles) to An-Nubuwwah containing justification and deception and Al-Risala. It contains obedience and iniquity. Which belongs to the category of al-treatise there are three areas; a) ash-Sha'air (ritual of faith) such as establishing prayer, performing zakat, fasting ramadhan and other forms of worship mahdah b) Morals and c) legislation (shari'a).

For Syahrur, the life exemplified by the Prophet only provides a model for contemporary Muslims, in the sense that he has lived according to Allah's message. Not understanding that it should make the same choice with him (absolutely). Muhammad's life is a first variation in history of how Islamic rule can be applied in tribal societies at the time. However, it is only the first variation not the only and not the last.

In other words, the Prophet's position for Syahrur as the first mujtahid who had grounded the absolute divine laws through the sunnah according to the needs and conditions of the moment. The Sunnah of the Prophet is seen as the "true early mirror" (al-mir'ah al-Sādiqah al-Ūlä) for the understanding and application of divine law which is the result of the interaction of God's revelation and the objective world at that moment. However, the sunnah of the Prophet is not the only form of understanding the Qur'an and not the last form of the application of divine laws. Only the Sunnah of the Prophet which is related to the ritual (worship) and ethical norms that is valid at all the time.

This means that it is not only the sunnah (the traditions and sayings of the prophet), but the ideal society still needs to be understood according to the recitation of the Qur'an. One must uphold the Prophet Muhammad and his companions as interpreters but not exaggerate their interpretation, merely 
because they "read" the revelation received on the basis of their intellectual capacity and world view, so that contemporary Muslims should read the text based on their own worldview.

So in the matter of legislation that is in the public affairs (muamalah broadly) we may interpret objectively according to the development of the present world. In this case Syahrur offers two core methods (1) semantic linguistic analysis (hermeneutics) and (2) the application of modern sciences such as analytic mathematics, analytic techniques and set theory.

\section{Theory of the Boundaries (Nazhariyyah Al-Hudūd)}

Linguistically, the word hudūd is a plural form of the Arabic word al-Hadd which means al-hajiz bain shai'aini (the separator between two things); an-nițāq, al-mādah, al-ghāyah, al-muntahā, al-taqyìd, al-hasr, al-kabh (limits); and al-man'u, al-mamnu 'wa almahzur which means prohibition. Al-hadd means a ban because something is called hadd when a person is forbidden to return to it. Syahrur himself uses hudūd term as a limit and not as a prohibition. This meaning is also used by syarur when he understood the Word of Allah SWT, Q.S. al-Nisa 13 - 14:

(Those laws) are the provisions from Allah. Whoever obeys Allah and His Prophet, surely Allah puts them into heaven which flows rivers in it, and they abide in it; and that's a big win.

And whoever disobeys Allah and His Propets and violates His provisions, Allah will put them into the fires of hell while they abide in it; and to them a humiliating punishment.

The discussion of hudūd in the above verse refers to the preceding verses, namely the provision of inheritance. The provision of inheritance is not a prohibition, but a content, size or limitation. Thus hudūd in the context of the above verse can be understood as the limit as Syahrur understands.

Syahrur asserted that the theory of limits is one of the approaches in ijtihad, which is used in studying the verses of muhkamat (verses containing legal messages) in the Qur'an. The 
term limit (hudūd) used by Syahrur refers to the notion of "the boundaries of Allah's provisions which should not be broken, but within it there is a dynamic, flexible, and elastic ijtihad region". The idea of boundary theory is acknowledged as reflection in the field of engineering that is as a scientist of physics ${ }^{7}$.

Hudūd in the terminology of fuqaha is defined as a punishment (uqubah) which has been determined by Allah and is His right. Therefore, the punishment should not be reduced and should not be added. Thus hudūd is only known from the text of the explicit nash, should not be based on the meaning of implicit nash or ijtihad. In other words hudūd is a punishment that has been clearly defined by the text (texts of the Qur'an and Sunnah) which can not be reduced or added in any form. In order to explain the understanding of hudūdlike this, Abdul Qadir Awdah writes:

"... Al-Hadd is a predetermined punishment and is Allah's right. The purpose of the prescribed punishment is that the punishment is already restricted, predetermined, no more minimum and maximum limits. While the intent of the punishment does not apply on the cancellation either from person to person or group of people ".

The explanation of Awdah contains the consequence that what has been triggered by Syahrur about the hudūdtheory clearly contradicts or violates the "grip" fuqaha. However, Ar-Raghib AlAshfalani disagrees in this regard, according to him the meaning of the word had in the Qur'an includes the laws of Allah which consists of: (a) laws that should not be exceeded, either by adding or reducing, such as raka'at in fardhu prayer; (b) laws that may be added but should not be reduced; (c) laws that may be reduced but not added. Thus, the existence of minimum and maximum limits in the Qur'an is justifiable.

In the view of fuqaha, hudüd becomes the name for seven types of criminal act, namely adultery, qadzaf (accusing adultery), drinking khamr, stealing, robbing, apostasy and al-bughat

${ }^{7}$ Nasr Hamid Abu Zaid, Prinsif Dasar Hermeneutik Al-Qur'an (Yogyakarta: Elsaq, 2004), 17. 
(rebellious). In addition, hudūd is also used as a name for punishment to be given to the perpetrators of the seven crimes. The punishment of the seven offenses is explicitly mentioned in the Qur'an and Sunnah; had zina (Surah an-Nur: 2) had qadzaf (Surah. an-Nur: 4) haddrinking of khamrHadith of the Prophet: "... an-Nabi SAW kana yadhribu fi al-khamr bi at-ta'al wa al-jarid arba'in ". (Surah Al-Maidah: 38) had robbery (Surat al-Maidah: 33) had apostasy (Prophet's word "man baddala dinahu faqtuluh" (Narrated by Bukhari) and had rebelled (Surah Al-Hujarat: 9) This is the area of hudūd talks among fuqaha.

The word hudüdin the Qur'an is mentioned at least thirteen times in eight verses:

1. Once in Q.S. al-Baqarah verse 187. In this verse the word hudūd means a prohibition. The fall of this verse refers to a friend who was about to mingle his wife when he was doing i'tikaf at the mosque.

2. Four times in Q.S. al-Baqarah verse 229, the word had / hudūd in this verse means laws or provisions. The fall of this verse refers to the conjugal quarrels and how Allah'a provision provides the solution.

3. Twice in Q.S. al-Baqarah verse 230. Here the word hudūdmeans the laws or provisions because the decline of this verse relates to the events of talaq ba'in and how Allah's provisions concern it.

4. Once in Q.S. al-Nisa verse 13, in this verse the word hudüdmeans the provisions (laws)

5. Once in Q.S. al-Nisa verse 14. Here the word hudūd means the provisions by looking at the similarity of the theme of the previous two verses it can be concluded that verses 13 and 14 can not be released from the previous verse relating to the division of inheritance and how the provisions of Allah about it 
6. Once in Q.S. al-Taubah's verse 97, in this verse the word hudüd means laws

7. Once in Q.S. Al-Mujadalah verse 4, in this verse the word hudūd also means laws. Because the decline of this verse relates to Khawlah binti Tsa'labah who complained to the prophet after being zhihar by her husband Aush Bin Shamit, the verse explains the punishment for the husband who zhihar his wife.

8. Twice in Q.S. al-Talaq verse 1 , which the hudūd word in this verse also means the laws. This verse goes down in relation to Siti Hafsah's talaq by Rasulullah although later Jibril reminded the prohet to reconcile because Hafsah is the fasting expert and diligent in waking up at night. In this verse the prophet is commanded to give waiting time for Hafsah until her iddah ends.

From the above hudūd words mentioned above it can be concluded that the word hudūd in the Qur'an shows more of the meaning of family law and not the punishment law (uqübah) in the criminal area as understood by most fuqaha. Thus what is proposed by Syahrur with the hudūd theory, as inspired by Sir Isaac Newton modern western physicist who developed the concept of mathematical hudūd and mathematical analysis, in fact there is no problem either linguistically or syar'i.

The limits set by Allah (hudūd) are likened by Syahrur as straight and constant lines, while at the same time giving man space to move dynamically (al-taghayyur) in law. In other words, these limits are representations of the side of the robustness of the law that is timeless and hot and not weathered by rain (Syahrur describes this boundary as $\mathrm{Y}$ axis). While the space conferred by these boundaries represents an ever-dynamic side of the flexibility of Islamic law according to time development guidance (Syahrur describes the context of time and history development as the $\mathrm{X}$ axis). The combination of something constant (al-Thawābit, Y axis) and something that changed (al-taghayyur, $\mathrm{X}$ axis) is the essence 
of Islamic law formulated by Syahrur. Therefore, Islamic law by Syahrur is defined as civil law which in making it should pay attention to boundaries the limits that Allah has given.

Based on his review of the legal verses, Shahrur has concluded six forms in the theory of limits. First, the rule of law ${ }^{8}$ that only have the lower limit (al-hadd al-adna). This happens in the case of: various women who should not be married (Q.S. al-Nisa: 22-23), various kinds of food that is forbidden (Q.S. al-Maidah: 3, alAn'am 145-156), debts (al-Baqarah: 283-284), and women's garments (al-Nisa: 31 ).

\section{a. Minimal Limit (al-hadd al-adnâ)}

According to Syahrur, Allah has given humans the minimum boundaries that should not be exceeded so that it becomes even more minimal. The minimum limit is already the lowest limit given by Allah about a human act that can be done. Among the minimum limit that has been disclosed Syahrur is the minimum limit in terms of prohitions in marriage. The minimum limit is the relatives mentioned in the Q.S. al-Nisa: 22 and 23. All the relatives mentioned in this verse are the minimum boundaries that should not be negotiable.

And do not marry women whom your father has married, except in the past. Verily, the deed is very vile and hated by Allah and the worst way (taken).

Forbidden on you marrying your mothers; your daughters [281]'; your sisters, your father's relatives who are women; Your mother's relatives who are women; daughters of your male brothers; daughters of your sisters; your mothers who breastfed you; a sister; your wife's mothers (inlaws); the sons of your wives who are in your care from the wives whom

${ }^{8}$ M. Amin Abdullah, Paradigma Alternatif Pengembangan Ushul Figh (Yogyakarta: ar-Ruzz, 2002), 136-137.

${ }^{9}$ Maksud ibu di sini ialah ibu, nenek dan seterusnya ke atas. dan yang dimaksud dengan anak perempuan ialah anak perempuan, cucu perempuan dan seterusnya ke bawah, demikian juga yang lain-lainnya. sedang yang dimaksud dengan anak-anak isterimu yang dalam pemeliharaanmu, menurut Jumhur ulama termasuk juga anak tiri yang tidak dalam pemeliharaannya. 
you have been with, but if you have not interfered with your wives (and you have divorced her), then sinless if you marry her; (and forbidden for you) the wives of your children (in-laws); and bring together (in marriage) two sisters, except those that have happened in the past; Allah is Forgiving, Merciful.

A person is permitted to marry those who have a kinship relationship further than those mentioned in that verse or persons who have no kinship with him/her. In addition to prohibition to marriage, the minimum limit is also found in terms of foods that are forbidden, as contained in Q.S. al-Maidah verse 3, Q.S. al-An'am verses 19 and 145. Then based on the above verses Syahrur concluded that the minimum limit in the issue of forbidden food is carrion, blood and pork. The strangled, beaten, gored and which was attacked by a wild beast as long as not slaughtered by Allah's name into the category of carcasses.

In addition to the two issues above Syahrur holds that Q.S. alBaqarah: 282-283 is a verse that contains a minimum limit in terms of accounts payable. In this verse Syahrur understands that for the problem of debts there must be written evidence in order not to cause any doubt in the future. Syahrur seems to see this verse as a verse that contains a minimum threshold with the understanding that in the matter of debts there must be at least written evidence. Larger evidence than that is allowed, but debts are not allowed without evidence. Minimal limits are also present in the issue of women's clothing, where all women must obey it because it is a duty of Allah as set forth in the Q.S. al-Nur: 31. The other minimum limit that Syahrur exemplifies is punishment for the murder of an innocent (unintentionally). The minimum penalty limit of this case is to free a believing slave. However, if not able then they may fast two consecutive months (Q.S. al-Nisa: 92).

b. Maximum Limit (al-hadd al-a'lā)

In Syahrur's view, the maximum limit lies in the theory of punishment in cases of theft and intentional killing. The cuttingoff of the hand for the thief and the punishment verse for the 
murder case is a verse that contains the maximum limit. According to Syahrur's understanding, in the verse of theft Allah gives the maximum limit of punishment for the thief, specifically cut off his hand. Therefore, humans should not punish more heavily from hand-cuts over theft cases (Surah Al-Maidah: 38) based on that verse, humans can only be punish with less punishment than that. of what theft should be punished lower than that, according to Syahrur it becomes the duty of the Mujtahids to determine according to the prevailing circumstances.

Syahrur further added that the thieves who stole the state secret and sold them to other countries, thieves who stole treasure by using guns violence or by corporate means or fictitious proposals, the thieves of state property (corruptors), policy holders who actually contributed to the economic crises that miserable the people, which undermines the state by placing people in the wrong positions, drug dealers, destroyers of institutional buildings, bridges, fortresses, energy stations and so on, can not be included in the category of theft whose maximum penalty is cutting off hands. In this case Syahrur included them in a severe rebel rebate and the punishment was so severe as stated in verse 33 of al-Maidah.

Indeed revenge upon those who fight Allah and His prophets and make mischief on earth, only they are killed or crucified, or cut off their hands and feet with reciprocity, or thrown out of the land (his residence). Such an insult for them in the world, and in the Hereafter they shall be subject to great tribulation.

Based on this verse, Syahrur supposes that the rebels and destructive creators on earth are not enough to just to receive cut hands. They should be punished more heavily than that, as the above verse states that the punishment is to be killed or cut off by hand or foot alternately or imprisoned for life, except before being punished he expresses apologies as stated in Q.S. Al-Maidah: 15. In this case Syahrur added that it is the duty of the members of the 
panel of judges to determine what punishments of the above three alternatives are relevant for a case of rebels and the culprit.

The maximum limit is also present in the verse which speaks of the punishment for the perpetrator of murder on purpose. The maximum penalty is the punishment of qișas (Q.S. al-Baqarah: 178). For the murdered family, it is again warned not to exceed the limit when executing the qishas punishment.This means that they should not be tyrannous or hostile and vengeful, such as killing the killer as well as the whole family and his relatives in giving back punishment.

c. Maximum and Minimal Limits come simultaneously, but not together in a single line.

This limit appears in the verses of inheritance (Q.S. al-Nisa: 11,12, 13 and 14) and the male restriction and may marry four women (Q.S. al-Nisa: 3). As Syahrur reveals in Nahw Ușül JadIdah that the inheritance verses should be understood as a general rule of wanting to provide justice at the level of men's and women's groups, not just at the personal level, so that understanding must use the principles of set and modern mathematics, hence Syahrur gives a unique interpretation of the verses of inheritance above.

Syahrur also gives a unique insight to the verses of polygamy (Q.S. al-Nisa: 3). He sees this verse as hudüdiyah verse. Its presence is to combine the maximum and minimum limits in a quantity and quality at once. In terms of quality, the minimum limit of polygamy is one, while the maximum limit is four. While in terms of quality, the second to fourth wife must be a divorced widow (lost husband) -not divorced-which still has the dependence of orphans. Thus, the minimum hudūd of polygamy is one and the maximum hudūdare the four wives with the second to fourth wife record is the divorce widow who lost her husband who still has dependents of the children. 
d. Maximum and minimum limits that integrated into one point or one line

This limit exists only in one verse and is not in sunnah, precisely in the verse about the penalty for the people who commit adultrery. That one point has one hundred volumes (QS An-Nur: 2)

A woman and a man who commits adultery, shall every one of them be lashed one hundred times, and let not mercy on them both who prevent you from practicing the religion of Allah, if you believe in Allah, and the Hereafter, and let the execution of their punishment be witnessed by a group of believers.

This verse made by Syahrur as the maximum and minimal limit which is united in one point which in this verse there is an explanation that do not give mercy to both (wala ta'khudzkum bihima ra'fatun fi din Allah). This means we should not give them any relief. That is to say, the punishment is already a minimum penalty and a maximum limit. It is worth knowing that from this one hundred punishment penalty that it is almost certain that no one can survive on it. Furthermore Syahrur provide conditions and circumstances when this punishment can be implemented. The condition is the existence of four witnesses or the existence of mula'anah (accusing adultery) between husband and wife. Thus Allah did not entrust this issue of punishment of adultery to the Mujtahids, this is according to Syhrur the only tasyri'aini in Islam.

e. Maximum limit of a line approaching a straight line but not touched

In this case Syahrur exemplifies the relationship of men and women who have not committed adultery (Q.S. al-Isra: 32 and Q.S. al-An'am: 151). Which is specific to the fifth hudüd according to Syahrur is closely related to the fourth type before, in this limit one can not approach the maximum limit because the maximum limit is not to approach itself. The problem that is not approaching can not be positivizated. This depends on decisions and judgments on mujtahids. 
f. The maximum limit that is positive, closed and should not be exceeded, while the minimum limit is negative and may be exceeded in a negative direction

This type of boundary theory applies to material transactions laws, the maximum limit of usury, while the minimum limit of zakat. Usury should never be exceeded, while zakat may be exceeded in a negative direction with the payment of alms. Between these two boundaries there is a zero position, manifested in transaction al-qardh al-hasan (interestless loan).

With his boundary theory he believes that Muhammad's treatise will truly prove as rahmatan lil alamin and shalih fi kulli zaman wa makan. Because based on this theory Islamic laws have a very high dynamics and elasticity to accept various forms of the times and places of action within certain limits. In addition, he believes that this treatise has the same basic nature as every object in the universe, including humans, which is always moving dynamically within certain limits. So it is believed that Islam will live up to doomsday.

\section{The Concept of Space and Time Dialectics in Islamic Law}

Jadal (dialectic) in Arabic comes from the root word ja-da-la, which means deciding something in the ongoing conversation (alistirsal), extending the resistance and repeating the conversation (Ibn Pharisa). While al-istirsal comes from the word ra-sa-la which means "wavy" and "spread". Dialectics is based on the duality principle which has several forms, among others: first, inhern duality in a material form. This duality leads to an internal dialectic based on one-way resistance, between two elements that are all material things. This is a dialectic that leads to the continuous destruction of the form of something.

Second, the oppositional duality between two material, between which they are met by a certain relation. This duality leads to an external dialectic between the two based on non 
contradictory opposition in two directions. This means that this dialectic is based on mutual reciprocal interaction between two things causing harmony between the two. This is a dialectic which leads to harmony between two paired.

Third, duality coincides between two phenomena that can never be reconciled, because one existence will deny the existence of the other. This duality leads to the dialectic of resistance in the phenomenon of the non-organic physical world as a result of the motion of the mechanisms of solid objects, such as day and night comings. Besides, this kind of duality will lead to the dialectic of resistance in the organic world as a result of the organic movement of living things, such as the passage between sniffing motion and blowing at the time of breathing or the passage between gestures open and grasping hands. This dialectic of resistance is based on contradictory opposites in tandem. This is the dialectic of the opposite between two opposites.

Fourth, the inhern duality between two opposites, which both are not material. Both are reunited within the human brain based on two-way resistance between the two. Sometimes this dialectic ends in the human mind with the emergence of one decision in each opposition separately, one of which is strengthened, while the other is ignored. The law or decision becomes true, in the sense of being real, if it has a correlation with objective material reality that is outside the human. Likewise, the decision is false, in the sense of illusion if it has no correlation with objective reality, then on this basis is the human dialectic.

Sometimes dilektika between the two opposites in the human mind does not end with the making of a decision, because at that moment there is the dominance of feeling (not rational) from one to the other, such as it appears in the dominance of feelings of love or hatred or vice versa, then with this what happens is the dialectic of the human psyche. 
a. Inherent Dialectics, Internal Dialectics in something one (the dialectic that causes the destruction of something)

The internal conflict between two opposing elements for everything that leads to continuous change of form. It manifests in the destruction of the form of everything which is then followed by the appearance of another form. This conflict is a secret of evolution and constant changes in the cosmos as long as this cosmos exists. This is what is called the "internal dialectic movement" which is often also termed "negation" and "negation insertion"10. In the Qur'an this dialectic is termed tasbih ;

The seven skies, the earth and all that is in it glorify Allah. And there is none but glorification by praising Him, but you do not understand their rosary. Verily he is the Most Merciful and Forgiving. (Q.S. Al-Isra: 44)

"What is in the heavens and on earth glorifies [yusabbihu] to Allah" (Q.S. Al-Hadid: 1, Al-Hasyar: 1, and Al-Shaff: 1). "What is in the heavens and on earth always glorify [yusabbihu] to Allah (Q.S. al-Jum'ah: 1 and Q.S. alTaghabun: 1)

The word al-tasbihis a derivation of the word sa-ba-ha which means "to move continuously, like floating on water". This is what Allah says about the motion of all things."Each one moves in its orbit". This resistance leads to the change of everything and of itself so that we can conclude that death is a real thing and only Allah is everlasting and eternal.

In connection with this Syahrur also argued that the opinion that says that Subhān Allah is a form of purification of Allah from all forms of deficiency and shame is out of date. However the concept of deficiency implies epistemic and sociological understanding in the context of humanity that contains understanding is relative, because the concept of lack or shame always changes from one place to another and from one time to another. The ultimate essence of all things in its being, to Allah SWT is to return to the existence of Allah which is the source of

${ }^{10}$ Muhammad Syahrur, Dialektika Kosmos Dan Manusia; Dasar-Dasar Epistemologi Qur'ani (Bandung: Nuansa, 2004), 39. 
internal-dialectic motion in everything, since Allah created the cosmos. Whereas God in His essence is free from this motion, He is the One, and becomes the place of all things dependent. There is nothing that is equal to Him. That is because this movement will lead to the destruction of all things, that is death.

This law will not stop in the process, except with the cosmic explosion which will lead to its destruction. The Qur'an has signaled this by the first trumpet blast [al-shur], which will be subsequently replaced by another cosmos (tiupanterompet). The substance of the matter will change with the cessation of the internal resistance law of contradictory things to be substituted by the law of new material in which the material appears composed of two elements which one of them is connected with another with a dialectical opposite. It will appear to him a permanent form which is manifestly manifested in the phenomenon of eternity in the Hereafter, in which there is no birth, no death but development, but that there is a continuous motion with an entirely different formulation.

The internal law of resistance of the opposites (duality in one being) is based on the mutually approaching and mutually exclusive relationship (the contradiction between the two elements that constitute a material thing that both exist simultaneously in something), both of which causing a movement in him which then bring the form of something continuously. This law works internally in everything that is material - without exception. The motion towards each other and each other away represents a continuous contradiction that results in motion within the self. That creates continuous change (the destruction of form and birth of new forms, and so on). The ideal expression of this law is contained in the Qur'an; "All things shall perish except His face" (Q.S. al-Qașaṣ: 88). 
b. External dialectics between two things, the two paired harmonic dialectics (the process of adaptation)

The term al-zauj (couple) is contained in many verses among them, "That He has created two in pairs, male and female" (Q.S. alAn'am: 45). Al-zauj in Arabic is a word that does not have the form of mu'anas (plural used for the context of women) in which the male is (zauj) the spouse of the female likewise vice versa the female is (zauj) the spouse of the male.

The law of "spouse" is the second basic law that everything in this material is subject to Him. The noble Qur'an has described a dualist relation or relationship between two things, some of which can be distinguished from others and deal with one another in a particular problem with the term "azwaj". This relationship encompasses all the forms that exist in nature. This relationship is the external relationship between something "zauj" with something else opposite "zauj". This law affirms that all things in the material cosmos, partly with others, can not be separated. It must therefore have an oppositional relationship with everything else at an infinite level.

The couple (zaujiyyah) is not a relationship between two elements in one self, but an external relationship between two opposing things (two in pairs), whether they are known or unknown. We can describe it as a relationship of mutual influence (the dialectical relationship between the two). On this basis we can not say the existence of an external dialectical relationship between two things, except after being constrained by an oppositional relationship (zaujiyyah) between the two as well as the degree of opposition of this relationship.

The oppositional relationship between the two in pairs is the external relation between two things based on the principle of the influence of mutual. With this legal basis can be constructed the law of adaptation to the physical world. A reciprocal relationship of mutual influence between two things which is partly 
indistinguishable from the other, in the sense that two pairs lead to continuous adaptation and harmony between the two.

This dialectical law operates on something by a noncontradictory external-oppositional dialectical relationship between two things, some of which can be distinguished from others by way of mutual influence. This relationship exists in varying degrees of the ideal form of this law contained in the Qur'an; "And every thing we have created in pairs to make you conscious". (Q.S. al-Ẓāriāt: 49)

c. Human Dialectic and knowledge

Basically al-haqand al-batil(the riil [al-haqīqah] and illusory [al-wahm) in the human mind mingle with a dialectical pattern of relationships, without ever ceasing. The real truth, al-haq is separated from the falsehood [illusi, al-bāti] for a certain period of time, then soon will re-assimilate with new patterns so it needs to be separated again, and so on until Allah SWT destroys the earth and what is on it.

Allah (SWT) likened the mixing of truth with falsehood to water mixed with mud, which water needs to be filtered and sterilized again to become clear. In addition, the metaphor is like iron in the form of metal that exists in the bowels of the earth, which needs to be heated in high temperatures to separate the iron from the dirt.

Allah has sent down water from the sky. So water flows in the valleys according to its size, so the current carries a floating scum. And from what (metal) they melt in fire to make jewelry or tools, there is also a foam like the foam of the stream. Thus Allah makes the parable of the true and the fool. As for the froth, will disappear as something of no value; As for the benefit of man, He remains on earth. Thus Allah makes parables ${ }^{11}$ (Q.S. al-Raad: 17$)$.

${ }^{11}$ Allah mengumpamakan yang benar dan yang bathil dengan air dan buih atau dengan logam yang mencair dan buihnya. yang benar sama dengan air atau logam murni yang bathil sama dengan buih air atau tahi logam yang akan lenyap dan tidak ada gunanya bagi manusia. 
The verse is one of the Qur'anic verses that underlies human knowledge with the eternal separation between the real truth and the illusion, in which both are bound by a pattern of contradictorydialectical relationships. The function of human knowledge is to establish a separation between the real (the intrinsic) and the illusion (wahm). Hence He has spoken to the Bani Isra'il;

And do not confuse the right with the false and do not hide the right, while you Know (al-Baqarah: 42).

The verse states that after separating the haq and the false then it should not be mixed for a second time. The Prophet (s) had separated the mix between the haq and the false among the Arabs in the 7th century. Because of his courage in separating the mixture there was an internal confrontation, that is, the destruction of falsehood and the correction of mistakes. For then the Arab-Islamic country formed with such a strong starting point. The Prophet (s) had separated the illusions of ignorance and idolatry, from the essence of objective truths in Arab and political epistemic thought in the seventh century.

After that, a second mixing occurs with a new formula. Responding to such thing as a Muslim who has an obligation to relinquish the mixing for the umpteenth time in this 20th century. Thus it is clear that the urgency of epistemology is to hold a continuous separation of the mixture. The Qur'an has provided the epistemological foundations for man, namely the foundations for separating truth from falsehood. The foundations of human epistemology come from the Qur'an.

\section{Conclusion}

Syahrur's language approach in studying the Qur'an ultimately led him to draw the conclusion that his legal product is highly dependent on the socio-cultural context. Syahrur considers the need for reinterpretation of the Qur'anic texts in the hope of synchronizing the texts with the reality of society whenever and wherever. Syahrur's focus on the Qur'anic texts makes him not to 
believe in al-Sunnah al-Nabawiyya as a source of law as well. For him, the Qur'an is sufficient because his verses have contained rules to answer the reality of life. To realize his idea, Syahrur drafted the Limit Theory (Nazoriyyat al-Hudud). With this Limit Theory, Syahrur tried to apply the muhkamat al-Qur'an texts into the reality of life with its limitations. The laws in the Qur'an according to him are elastic that can be drawn and adapted to the context of place and age. The condition of the society rests within the scope of the boundary, and as long as it does not exceed the prescribed limitations, the law is permissible.

\section{References}

Abdullah, M. Amin. Paradigma Alternatif Pengembangan Ushul Fiqh. Yogyakarta: ar-Ruzz, 2002.

Abu Zaid, Nasr Hamid. Prinsif Dasar Hermeneutik Al-Qur'an. Yogyakarta: Elsaq, 2004.

Sahrur, Muhammad. Al-Kitab Wal-Qur'an: Qira'ah Mu'ashirah. Kairo: Sina Publisher, 1992.

Shaleh, M. Abied. Islam Garda Depan. Bandung: Mizan, 2001.

Syahrur, Muhammad. Dialektika Kosmos Dan Manusia; DasarDasar Epistemologi Qur'ani. Bandung: Nuansa, 2004.

Syamsudin, Sahiron. Metodologi Fiqh Islam Kontemporer. Yogyakarta: el-SAQ Press, 2004. 